\title{
KARAKTERISTIK ORGANOLEPTIK FLAVOR ALAMI DARI KALDU KEPALA IKAN TONGKOL (Euthynnus affinis)
}

\author{
Devi Elizabet Pardede ${ }^{1}$, Devi Febrianti ${ }^{1}$, R. Marwita Sari Putri ${ }^{2}$ \\ ${ }^{1}$ Mahasiswa Teknologi Hasil Perikanan, Universitas Maritim Raja Ali Haji \\ ${ }^{2}$ Dosen Teknologi Hasil Perikanan, Universitas Maritim Raja Ali Haji \\ wita@umrah.ac.id
}

\begin{abstract}
Abstrak
Tujuan penelitian ini untuk mengetahui formulasi terbaik pada pembuatan flavor pasta dan bubuk alami dari air rebusan kepala ikan tongkol (Euthynnus affinis). Metode yang digunakan dalam penelitian ini yaitu metode eksperimental,dengan lima perlakuan penambahan kepala ikan tongkol sebanyak 23 $\%, 24 \%, 25 \%, 26 \%$, dan $27 \%$. Parameter yang diamati dalam penelitian yaitu uji organoleptik (uji hedonik). Kemudian di analisis menggunakan SPSS 25 untuk memperoleh perlakuan terbaik. Hasil penelitian menunjukkan bahwa flavor pasta yang diberikan perlakuan berbeda menunjukan tidak adanya pengaruh yang nyata (P>5\%) terhadap tingkat kesukaan panelis. Hasil penelitian uji hedonik panelis terhadap penampakan, warna, aroma dan rasa flavor kepala ikan tongkol dengan perlakuan penambahan kepala ikan tongkol yang paling disukai adalah perlakuan $26 \%$. Berdasarkan hasil penelitian ini dapat disimpulkan bahwa flavor bubuk limbah dari kepala ikan tongkol terbaik yaitu pada perlakuan P5 dengan konsentrasi kepala ikan tongkol 27\%. Hasil penelitian menunjukkan bahwa bubuk flavor yang diberikan perlakuan berbeda menunjukan adanya pengaruh yang nyata $(\mathrm{P}<5 \%)$ terhadap tingkat kesukaan panelis.
\end{abstract}

Kata Kunci : Flavor, kepala ikan tongkol, flavor pasta, flavor bubuk.

\section{PENDAHULUAN}

Indonesia merupakan salah satu negara yang memiliki potensi perikanan terbesar di dunia. data Kementerian Kelautan dan Perikanan sesuai dengan Kepmen KP No. 50/Kepmen-KP/2017, menyebutkan potensi lestari sumber daya ikan laut Indonesia diperkirakan sebesar 12,54 juta ton per tahun. Ikan sangat bermanfaat bagi manusia karena didalamnya terdapat berbagai macam zat-zat yang dibutuhkan oleh tubuh manusia seperti vitamin A, vitamin B1 dan vitamin B2.

Ikan tongkol (Euthynnus affinis) merupakan ikan air laut yang memiliki nilai ekonomis tinggi. Ikan tongkol (Euthynnus affinis) memiliki kelebihan yaitu kandungan protein yang tinggi serta kaya akan asam lemak omega 3 (Nuraini 2013). Ikan tongkol biasanya dipasarkan dalam keadaan segar atau beku. Sejumlah negara maju lebih menyukai ikan tongkol yang dipasarkan dalam bentuk potongan tipis (fillet) atau tanpa tulang (boneless) sehingga akan 
menghasilkan limbah dalam jumlah besar. Bagian dari ikan yang dibuang dan menjadi limbah adalah kepala, ekor, sirip, tulang, dan jeroan ikan yang pada umumnya meninggalkan limbah perikanan sebesar $35 \%$ dan menghasilkan daging rata-rata sebesar $65 \%$.

Flavor merupakan bahan tambahan pada makanan untuk menambah cita rasa pada makanan untuk memperbaiki kualitas rasa pada makanan. Persepsi flavor didefinisikan sebagai sensasi yang timbul dari integrasi (penggabungan) atau saling mempengaruhi sinyal yang dihasilkan sebagai akibat dari terdeteksinya komponen kimia oleh indera penciuman, indera perasa dan perunahan rangsangan dari makanan atau minuman. Persepsi panelis juga dipengaruhi oleh ketersediaan komponen volatile dan hasil interaksi antara komponen utama dan komponen aroma dalam makanan. Pelepasan flavor tergantung pada ketersediaan dari komponen flavor dalam fase gas dan afinitas antara komponen cita rasa dan matriks makanan. Sifat-sifat dari komponen flavor akan menentukan interaksi dengan komponen makanan seperti ukuran molekul, gugus fungsional, bentuk dan volatilitas (Naknean dan Meenune 2010).

Banyaknya permintaan masyarakat terhadap penyedap rasa maka pemanfaatan limbah kepala ikan tongkol dapat menjadi flavor pasta alami yang dapat menggantikan Mono Sodium Glutamate (MSG) sehingga masyarakat dapat beralih dari penyedap sintetis ke flavor pasta alami yang dapat memperbaiki atau menambah cita rasa pada makanan. Flavor dapat dibuat dari campuran berbagai komponen flavor, baik yang alami maupun sintetik. Berdasarkan bentuknya flavor terbagi dari tiga jenis yaitu bentuk cair, pasta, dan padat.

Menurut Syah (2020) Kandungan yang terdapat didalam flavor pasta tamban yaitu protein $0,76 \%$, kadar air $62,44 \%$, kadar abu $13,42 \%$, karbohidrat $22,94 \%$. Asam amino yang diperoleh dengan nilai tertinggi yaitu Tirosin $0,18 \%$ dan yang memiliki nilai terendah yaitu serin $0,04 \%$ sehingga flavor tersebut bagus digunakan dalam skala panjang.

\section{METODE PENELITIAN}

\section{Bahan dan Alat}

Bahan utama yang digunakan adalah air limbah rebusan kepala ikan tongkol. Bumbu yang digunakan untuk pembuatan penyedap masakan yaitu bawang merah, bawang putih, merica, tepung maizena sebagai bahan pengental, tepung terigu sebagai bahan pengisi, garam dan air.

Alat-alat yang digunakan dalam pembuatan flavor pasta dan bubuk ini yaitu timbangan digital, pisau, sendok, kompor, panci, kuali, penyaring, wadah pengemas, spatula, kertas label, tisu, gelas ukur, thermo laser, nampan, wadah kecil untuk nimbang, oven, dan blender.

\section{Metode Penelitian}

Metode yang digunakan dalam penelitian ini yaitu metode eksperimental, dengan lima perlakuan penambahan kepala ikan tongkol sebanyak 23\%, 24\%, 25\%, 26\%, dan $27 \%$. Konsentrasi air yang digunakan untuk perebusan kepala ikan tongkol sebanyak $500 \mathrm{ml}$. Parameter yang diamati dari flavor pasta dan bubuk yang dihasilkan adalah karakteristik organoleptik yang meliputi rasa, 
penampakan, warna dan aroma. Uji organoleptik yang digunakan adalah uji mutu hedonik menggunakan panelis semi terlatih sebanyak 30 panelis. Hasil uji organoleptik dianalisis menggunakan SPSS 25 untuk memperoleh perlakuan terbaik dengan melakukan uji kruskawalis-test.

\section{Prosedur Penelitian}

Tahap-tahap penelitian bubuk flavor (modifikasi Ramadhani 2015) yaitu:

1. Kepala ikan tongkol yang segar dipotong-potong dan dicuci hingga bersih.

2. Kepala ikan tongkol yang sudah bersih kemudian dicampur dengan air dan garam.. Dengan perlakuan persentase ikan tongkol $23 \%, 24 \%, 25 \%, 26 \%$, dan $27 \%$.

3. Kepala ikan tongkol, dan air dicampur di dalam panci lalu direbus selama 30 menit dengan suhu perebusan $80-100^{\circ} \mathrm{C}$ dengan penambahan bumbu (bawang merah, bawang putih, merica, dan garam).

4. Kaldu hasil rebusan disaring dengan saringan lalu cairan kaldu (filtrat) yang tersaring/bebas ampas dipakai untuk tahap selanjutnya.

5. Kaldu (filtrat) diberi penambahan bahan pengental yang diberikan berupa tepung maizena untuk flavor pasta sedangkan pada flavor bubuk ditambahkan tepung terigu sebagai bahan pengisi sebanyak $15 \%$ dari berat filtrat yang dihasilkan. Setelah dicampur dengan bahan pengental lalu diaduk hingga homogen.
6. Kaldu yg telah ditambahkan tepung maizena dipanaskan lagi selama 7 menit dengan suhu 70 $80^{\circ} \mathrm{C}$

7. Flavor pasta tersebut kemudian dikemas dengan wadah.

8. Kaldu yang telah ditambahkan tepung terigu dilakukan pengeringan dengan menggunakan oven. Pasta flavor dihamparkan tipis-tipis, selama 90 menit dengan suhu $100^{\circ} \mathrm{C}$.

9. Flavor yang telah kering dihancurkan menggunakan blender hingga berbentuk bubuk, lalu diayak sehingga menghasilkan flavor bubuk yang bagus

10. flavor bubuk kemudian dikemas dengan wadah

11. Sampel flavor pasta dan bubuk yang sudah jadi dilakukan uji organoleptik (uji hedonik).

\section{Formulasi Flavor}

Pada pembuatan flavor pasta dan bubuk terdiri dari bahan utama berupa air rebusan kepala ikan tongkol serta bahan pendukung berupa bumbu-bumbu sebagai pemberi cita rasa. Adapun formulasi dalam proses pembuatan flavor pasta pada penelitian ini.

Tabel 1. Formulasi Flavor Persentase per

Berat Air yang Digunakan untuk Ekstraksi Kaldu

\begin{tabular}{lccccc}
\hline Perlakuan & P1 & P2 & P3 & P4 & P5 \\
\hline $\begin{array}{l}\text { Kepala ikan } \\
(\%)\end{array}$ & 23 & 24 & 25 & 26 & 27 \\
B. merah & 2 & 2 & 2 & 2 & 2 \\
$(\%)$ & & & & 2 & 2 \\
B. putih (\%) & 2 & 2 & 2 & 2 & \\
Merica (\%) & 0.1 & 0.1 & 0.1 & 0.1 & 0.1 \\
Garam (\%) & 5 & 5 & 5 & 5 & 5 \\
\hline
\end{tabular}

Sumber : Modifiksi Ramadhani (2005) 


\section{Uji Organoleptik (SNI 01-2346-2006)}

Uji organoleptik yang digunakan pada penelitian ini yatu uji hedonik dengan 30 panelis semi terlatih. Uji hedonik merupakan pengujian yang paling sering digunakan untuk mengukur tingkat kesukaan terhadap suatu produk berupa warna, aroma, rasa dan tekstur. Tingkat kesukaan ini disebut skala hedonik, misalnya sangat suka, suka, agak suka, netral, agak tidak suka, tidak suka, sangat tidak suka. Panelis akan menunjukkan tingkat kesukaan mereka terhadap masing masing sampel dengan memilih kategori yang sesuai. Metode pengujian yang dipakai dalam standar uji ini adalah uji skoring (scoring test), angka 1 (satu) menyatakan tidak suka, angka 2 (dua) menyatakan netral, sedangkan angka 3 (tiga) menyatakan suka.

\section{HASIL DAN PEMBAHASAN}

\section{Hasil Uji Organoleptik}

Uji hedonik merupakan cara pengujian menggunakan indera manusia sebagai alat utamanya. Karakteristik organoleptik yang diamati dengan uji hedonik menggunakan 30 orang panelis semi terlatih sesuai dengan SNI 012346-2006 yaitu penampakan, warna, aroma, rasa, tekstur dari flavor pasta dan bubuk kepala ikan tongkol.

\section{Warna}

Warna merupakan atribut fisik yang dinilai terlebih dahulu dalam penentuan mutu makanan dan terkadang bisa dijadikan ukuran untuk menentukan cita rasa, tekstur, nilai gizi dan sifat mikrobiologis (Nurhadi dan Nurhasanah, 2010). Warna merupakan faktor mutu yang paling menarik perhatian konsumen, warna memberikan kesan apakah suatu produk tersebut akan disukai atau tidak. Warna yang menarik akan mempengaruhi penerimaan suatu produk, karena umumnya penerimaan suatu produk pertama kali dilihat pada warna.

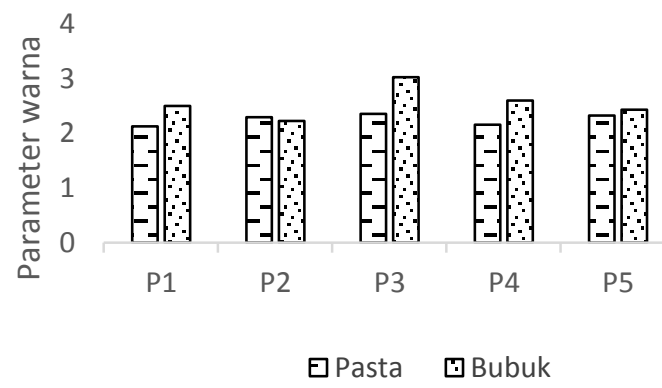

Gambar 1. Histogram hasil uji warna

Ket: $\quad$ P1 : Kepala ikan tongkol $23 \%$

P2 : Kepala ikan tongkol $24 \%$

P3 : Kepala ikan tongkol $25 \%$

P4 : Kepala ikan tongkol $26 \%$

P5 : Kepala ikan tongkol $27 \%$

Warna merupakan penampakan pertama yang dilihat langsung oleh panelis, kualitas mutu bahan yang digunakan sangat bergantung pada warna yang dimilikinya (Negara et al. 2016). Warna dapat berubah saat proses pemasakan, selain itu warna juga dipengaruhi dari persentase kepala ikan tongkol yang diberikan terhadap proses pembuatan flavor. Warna pada flavor dengan bahan tepung maizena dan tepung terigu memberikan pengaruh yang signifikan nyata terhadap penerimaan panelis pada flavor kepala ikan tongkol.

Hasil uji organoleptik skala hedonik warna memiliki nilai yang bervariasi untuk setiap perlakuan, dapat dilihat pada Gambar 1. Flavor dari kaldu kepala ikan tongkol menunjukkan hasil terbaik yaitu P3 dengan persentase kepala ikan tongkol $25 \%$ pada flavor 
pasta. Warna dapat berubah saat proses pemasakan, selain itu warna juga dipengaruhi dari persentase kepala ikan tongkol yang diberikan terhadap proses pembuatan flavor. Berdasarkan hasil penelitian terhadap warna flavor pasta ada produk yang tidak suka, netral dan disukai oleh panelis namun tidak ada produk yang ditolak atau tidak disukai oleh panelis. Nilai rata-rata warna flavor pasta berkisar 2,13 sampai 2,36 yang menyatakan netral. Berdasarkan hasil uji yang dianalisis menggunakan SPSS 25, terlihat tidak adanya pengaruh yang nyata dengan $>0,05$ terhadap warna flavor pasta yang dihasilkan.

Berdasarkan hasil penelitian terhadap warna bubuk flavor ada produk yang diterima biasa, agak disukai dan disukai oleh panelis namun tidak ada produk yang ditolak atau tidak disukai oleh panelis. Nilai rata-rata warna bubuk flavor berkisar 2,3 sampai 3 yang menyatakan suka. Warna bubuk flavor kepala ikan tongkol disukai oleh panelis karena warna kremnya identik dengan warna bubuk flavor sapi komersial, tidak terlalu keputihan maupun kecoklatan. Warna bubuk flavor yang berwarna kecoklatan disebabkan adanya proses pemanasan saat pengeringan (Ramadhani, 2015). Berdasarkan hasil uji pada panelis yang dianalisis menggunakan SPSS terlihat terdapat pengaruh yang nyata dengan nilai yang diperoleh $<0,05$ terhadap warna bubuk flavor yang dihasilkan.

\section{Aroma}

Aroma merupakan bau yang ditimbulkan dari produk makanan yang tercium oleh syaraf-syaraf olfaktori yang berada dalam rongga hidung (Negara et al. 2016). Aroma sangat berperan penting dalam pembuatan flavor dari air rebusan kepala ikan tongkol ini. Aroma khas ikan akan membuat panelis tertarik dengan produk yang dihasilkan.

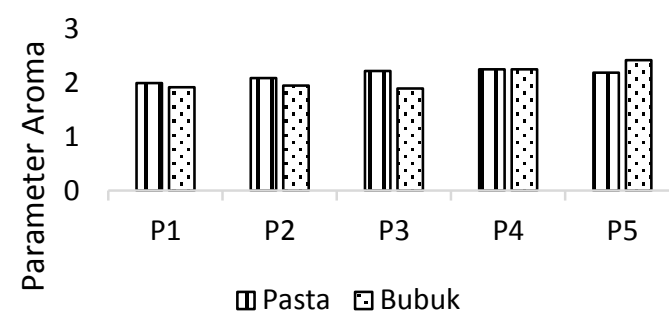

Gambar 2. Histogram hasil uji aroma

Ket: P1 : Kepala ikan tongkol $23 \%$

P2 : Kepala ikan tongkol $24 \%$

P3 : Kepala ikan tongkol $25 \%$

P4 : Kepala ikan tongkol $26 \%$

P5 : Kepala ikan tongkol $27 \%$

Aroma memainkan peran penting dalam produksi penyedap, yang digunakan di industri jasa makanan, untuk meningkatkan rasa dan umumnya meningkatkan daya tarik produk makanan tersebut (Antara dan Wartini, 2014). Aroma sangat berperan penting dalam pembuatan flavor air rebusan kepala ikan tongkol ini. Aroma yang enak akan membuat panelis tertarik dengan produk yang dihasilkan. Persentase kepala ikan tongkol sangat berperan penting pada setiap perlakuan, karena semakin tinggi persentase kepala ikan tongkol yang diberikan maka akan menimbukan aroma yang tidak sesuai harapan. Pengunaan kepala ikan tongkol dengan persentase yang tinggi akan memberikan aroma yang semakin pekat sehingga mengurangi kesukaan konsumen terhadap flavor kepala ikan tongkol.

Hasil uji organoleptik skala hedonik aroma memiliki nilai yang bervariasi untuk setiap perlakuan, dapat dilihat pada Gambar 2. Flavor dari air rebusan kepala ikan tongkol menunjukkan hasil terbaik yaitu P4 dengan persentase kepala ikan tongkol 
$26 \%$ pada flavor pasta yang berarti panelis menyukai aroma ikan tongkol yang agak pekat. Berdasarkan hasil penelitian terhadap aroma flavor pasta diperoleh nilai rata-rata berkisar 2 sampai 2,26. Berdasarkan hasil uji yang dianalisis menggunakan SPSS 25, terlihat tidak adanya pengaruh yang nyata dengan > 0,05 terhadap aroma flavor pasta yang dihasilkan.

Berdasarkan hasil penelitian terhadap aroma bubuk flavor diperoleh nilai rata-rata aroma bubuk flavor berkisar 1,9 sampai 2,4. Hasil rata-rata aroma tertinggi adalah perlakuan 5 dengan nilai rata-rata aroma sebesar 2,4 sedangkan hasil rata-rata aroma terendah yaitu perlakuan 1 dan 3 . Tepung terigu memiliki aroma yang tawar khas gandum atau tidak berbau tajam atau menyengat menurut Buckle et al., (2009) sehingga cocok digunakan sebagai bahan pengisi bubuk flavor kepala ikan tongkol. Hasil uji panelis, setiap perlakuan bubuk flavor kepala ikan tongkol tidak memiliki perbedaan aroma yang signifikan satu sama lain karena aroma kaldu ikan tongkol yang kuat. Berdasarkan hasil uji yang dianalisis menggunakan SPSS terlihat adanya pengaruh yang nyata dengan nilai $<0,05$ terhadap aroma bubuk flavor yang dihasilkan.

\section{Rasa}

Rasa makanan merupakan gabungan dari ransangan cicip, bau, dan pengalaman yang banyak melibatkan lidah. Rasa terbentuk dari sensasi yang berasal dari perpaduan bahanpembentuk dan komposisinya pada suatu produk makanan yang ditangkap oleh indera pengecap serta merupakan salah satu pendukung cita rasa yang mendukung mutu suatu produk (Pramitasari, 2010). Setiap panelis memiliki respon yang berbeda terhadap tingkat sensitivitas indrawinya namun perbedaan tersebut tidak akan jauh dari keragamannya, sehingga dibutuhkan panelis yang dalam kondisi baik dan tidak sedang menderita penyakit tertentu agar hasil pengujian tidak terdapat data yang eror (Syah, 2020).

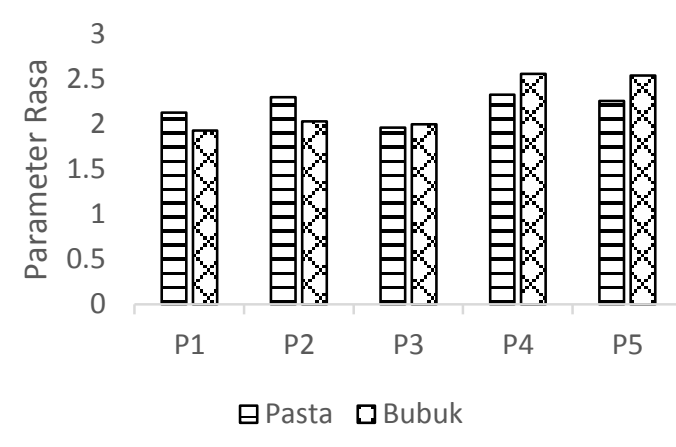

Gambar 3. Histogram hasil uji rasa

Ket: $\quad$ P1 : Kepala ikan tongkol $23 \%$

P2 : Kepala ikan tongkol $24 \%$

P3 : Kepala ikan tongkol $25 \%$

P4 : Kepala ikan tongkol $26 \%$

P5 : Kepala ikan tongkol $27 \%$

Pembuatan flavor pasta dari air rebusan kepala ikan tongkol ini dengan persentase kepala ikan tongkol sangat berperan penting, karena persentase yang berbeda akan memberikan nilai rasa yang bervariasi. Adapun bumbu-bumbu pada saat pembuatan formulasi seperti adanya bawang merah, bawang putih, garam dan merica membuat rasa dari flavor tersebut lebih gurih. Apabila persentase kepala ikan tongkol yang digunakan semakin tinggi maka dapat mempengaruhi rasa sehingga menjadi lebih pekat.

Berdasarkan Gambar 3 diatas dapat dilihat bahwa rasa pada flavor pasta dari air rebusan kepala ikan tongkol dengan perlakuan terbaik yaitu P4 dengan persentase kepala ikan tongkol $26 \%$ dengan rasa yang paling 
banyak yang disukai oleh panelis. Berdasarkan hasil penelitian terhadap rasa flavor pasta diperoleh nilai rata-rata rasa berkisar 1,96 sampai 2,33. Berdasarkan hasil uji yang dianalisis menggunakan SPSS 25, terlihat tidak adanya pengaruh yang nyata dengan > 0,05 terhadap rasa flavor pasta yang dihasilkan.

Berdasarkan hasil penelitian terhadap rasa bubuk flavor diperoleh nilai rata-rata rasa bubuk flavor berkisar 1,9 sampai 3. Hasil rata-rata rasa tertinggi adalah perlakuan 5 sedangkan hasil rata-rata rasa terendah yaitu bubuk flavor kepala ikan pada perlakuan 1 . Hasil uji panelis, setiap perlakuan bubuk flavor kepala ikan tongkol yang dicoba tidak ada yang memiliki perbedaan rasa yang signifikan satu sama lain karena rasa kaldu ikan tongkol yang kuat dipadu dengan rasa asin. Berdasarkan hasil analisis data dengan menggunakan SPSS terlihat adanya pengaruh yang nyata dengan nilai $<0,05$ terhadap rasa bubuk flavor yang dihasilkan.

\section{Tekstur}

Tekstur merupakan salah satu parameter yang digunakan pada saat uji organoleptik flavor yang bertujuan untuk mengetahui kekompakan dari flavor yang dihasilkan (Syah, 2020). Tekstur merupakan salah satu faktor yang menentukan penerimaan suatu produk. Penilaian tekstur bertujuan untuk mengetahui penerimaan panelis terhadap tingkat elastisitas atau kekenyalan suatu produk yang dapat dinilai menggunakan indera peraba, yaitu lewat rangsang sentuhan.

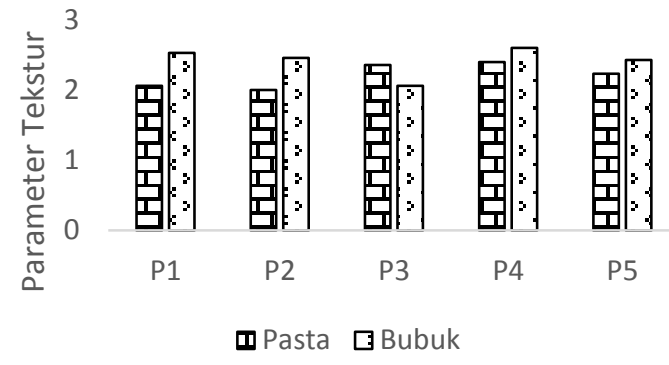

Gambar 4. Histogram hasil uji tekstur

Ket: $\quad$ P1 : Kepala ikan tongkol $23 \%$

P2 : Kepala ikan tongkol $24 \%$

P3 : Kepala ikan tongkol $25 \%$

P4 : Kepala ikan tongkol $26 \%$

P5 : Kepala ikan tongkol $27 \%$

Berdasarkan hasil uji organoleptik ternyata flavor dengan bentuk yang kental kurang diminati oleh panelis. Semakin lama pemasakan akan menyebabkan kenaikan viskositas dan penguapan air menjadi semakin besar, sehingga kadar air dalam bahan rendah dapat menyebabkan kenaikan viskositas (Syah 2020). Hal ini disebabkan karena air yang menguap akan semakin banyak dan total padatan terlarut semakin meningkat, sehingga viskositas akan meningkat. Semakin meningkatnya viskositas mengakibatkan tekstur produk semakin mengental dan akan berpengaruh terhadap hasil flavor yang diperoleh, (Nilasari et al. 2017).

Hasil uji organoleptik skala hedonik tekstur memiliki nilai yang bervariasi untuk setiap perlakuan, dapat dilihat pada Gambar 4. Setelah dilakukan uji tingkat kesukaan panelis terhadap flavor pasta ini menunjukan bahwa sampel perlakuan P4 yaitu dengan penggunaan $26 \%$ kepala ikan tongkol yang lebih disukai oleh panelis. Berdasarkan hasil penelitian terhadap tekstur flavor pasta, diperoleh nilai ratarata tekstur bubuk flavor berkisar 2 sampai 2,36. Berdasarkan hasil uji yang dianalisis menggunakan SPSS 25, 
terlihat tidak adanya pengaruh yang nyata dengan > 0,05 terhadap tekstur flavor pasta yang dihasilkan.

Berdasarkan hasil penelitian terhadap tekstur bubuk flavor, diperoleh nilai rata-rata tekstur bubuk flavor berkisar 2 sampai 3. Hasil rata-rata penampakan tertinggi adalah perlakuan pertama dengan nilai rata-rata penampakan sebesar 3 sedangkan hasil rata-rata penampakan terendah yaitu perlakuan 3. Tekstur bubuk flavor kepala ikan tongkol perlakuan 1 lebih disukai oleh panelis karena partikel serbuknya terlihat halus dan kering. Berdasarkan hasil uji yang dianalisis menggunakan SPSS terlihat adanya pengaruh yang nyata dengan $<0,05$ terhadap tekstur bubuk flavor yang dihasilkan.

\section{KESIMPULAN}

\section{Kesimpulan}

Persentase kepala ikan tongkol memiliki peranan penting dalam pengolahan flavor pasta dan bubuk yang dihasilkan, karena akan mepengaruhi terhadap warna, aroma, rasa dan tekstur yang dihasilkan. Berdasarkan uji organoleptik maka flavor pasta terpilih yaitu pada perlakuan $\mathrm{P} 4$ dengan konsentrasi kepala ikan tongkol 26\%, Sedangkan pada bubuk flavor perlakuan terbaik terdapat pada P5 dengan konsentrasi kepala ikan tongkol 27\%, sebagai perlakuan terbaik dengan mempertimbangkan tingkat kesukaan panelis.

\section{Saran}

Berdasarkan hasil penelitian yang diperoleh dapat disarankan bahwa perlu dilakukan penelitian lebih lanjut mengenai kandungan gizi pada flavor pasta dan bubuk serta uji masa simpan dari produk yang dihasilkan.

\section{DAFTAR PUSTAKA}

Adawyah RA, Aisyah S, Puspitasari F, Candra C. 2007. Penambahan Ekstrak Kepala Udang Galah (Macrobrachium Rosenbergii De Man) untuk Meningkatkan Kandungan Protein pada Produk Olahan Stick. Fish Scientiae. 7(1). 62-72.

Antara N, Wartini M. 2014. Aroma dan Komponen Flavor. Tropical Plant Curriculum Project. Udayana University.

Astuti S, Mustikanigrum M, Haryati M. 2012. Pembuatan Kecap Manis dari Limbah Ikan Tongkol (Eutgynnus Affinis). Industri Inovatif: Jurnal Teknik Industri. 2(2): 36-41.

Atika S, Handayani L. 2019. Pembuatan Bubuk Flavour Kepala Udang Vannamei (Litopenaus Vannamei) sebagai Pengganti Msg (Monosodium Glutamat). In Prosiding SemdiUnaya (Seminar Nasional Multi Disiplin Ilmu Unaya). 3 (1): 18-26. Haryati Y, Nurawan A. 2017. Peluang Pengembangan Feromon Seks dalam Pengendalian Hama Ulat Bawang (Spodoptera Exigua) pada Bawang Merah. Jurnal Penelitian dan Pengembangan Pertanian. 28 (2): 72-77.

Kemp SE, Hollowood T, Hort J. 2009. Sensory Evaluation: A Practical Handbook. Wiley Blackwell, United Kingdom.

Laksmi R. 2012. Daya Ikat Air, pH dan Sifat Organoleptik Chicken Nugget yang Disubstitusi Telur Rebus. Animal Agriculture Journal. 1(1): 453-460.

Liu JK, Zhao SM, Xiong SB. 2009. Influence of Recooking on Volatile and Nonvolatile Compounds Found in Silver Carp 
Hypophthalmichthys molitrix. Fish Sci. 75: 1067-1075.

Manurung LDI, Mustakim M, Siregar E. 2014. Pembuatan Flavor Limbah Udang (Panaeus monodon) dengan Komposisi Bumbu yang Berbeda. Berkala Perikanan Terubuk. 42 (1): 9-20.

Meiyani DNAT, Riyadi PH, Anggo AD. 2014. Pemanfaatan Air Rebusan Kepala Udang Putih (Penaeus Merguiensis) sebagai Flavor dalam Bentuk Bubuk dengan Penambahan Maltodekstrin. Jurnal Pengolahan dan Bioteknologi Hasil Perikanan. 3(2):67-74.

Midayanto D, Yuwono S. 2014. Penentuan Atribut Mutu Tekstur Tahu untuk Direkomendasikan sebagai Syarat Tambahan dalam Standar Nasional Indonesia. Jurnal Pangan dan Agroindustri. 2( 4): 259-267.

Naknean P, Meenune M. 2010. Review Article Factors Affecting Retention and Release of Flavour Compounds in Food Carbohydrates. International Food Research Journal. 17: 23-34.

Negara. J. K., Sio. A. K., Rifkhan, Arifin M., Oktaviana. A. Y., Wihansah R. R. S., Yusuf. M. 2016. Aspek Mikrobiologis serta Sensori (Rasa, Warna, Tekstur, Aroma) pada Dua Bentuk Penyajian Keju yang Berbeda. Jurnal Ilmu Produksi dan Teknologi Hasil Peternakan. Vol. 04 (2): 286-290.

Nilasari OW, Susanto WH., Maligan JM. 2017. Pengaruh Suhu dan Lama Pemasakan Terhadap Karakteristik Lempok Labu Kuning (Waluh). Jurnal Pangan dan Agroindustri. 5(3): 15-26.

Ningrum L. 2017. How The Panelists Votes Chicken Ballotine With Analog Chicken Turkey and Duck.
International Journal of Innovative Science and Research Technology. 2 (4).

Nurhadi B Nurhasanah S. 2010. Sifat Fisik Bahan Pangan. Bandung: Widya Padjajaran.

Peinado I, Miles W, Koutsidis G. 2016. Odour characteristics of seafood flavour formulationsproduced with fish byproducts incorporating EPA, DHA and fish oil. Food Chemistry. 212: 612-619.

Pratama RI. 2011. Karakteristik Flavor Beberapa Ikan Asap di Indonesia. [Tesis] Institut Pertanian Bogor. Bogor.

Pratama RI, Rostini I, Rochima E. 2018. Profil Asam Amino, Asam Lemak Dan Komponen Volatil Ikan Gurame Segar (Osphronemus gouramy) dan Kukus. Jurnal Pengolahan Hasil Perikanan Indonesia. 21(2): 218-231.

Ramadhani AR. 2015. Karakteristik Organoleptik Bubuk Flavor Kepala Ikan Tenggiri dengan Bahan Pengisi Tepung Terigu. [skripsi]. Universitas Padjadjaran. Bandung.

Rijal M. 2016. Pengolahan dan Peningkatan Kadar Protein Fish Nugget Berbahan Dasar Limbah Ikan dengan Pemberian Ekstrak Kulit Nanas. Biosel (Biology Science and Education): Jurnal Penelitian Science dan Pedidikan. 5 (1): 84-92.

Saanin H. 1971. Taksonomi dan Kunci Identifikasi Ikan. Jakarta: Bina Cipta. 245 hal.

Saleh M, Ahyar A, Murdinah M, Haq N. 2017. Ekstraksi Kepala Udang Menjadi Flavor Udang Cair. Jurnal Penelitian Perikanan Indonesia. 2(1): 60-68.

Sanger G. 2010. Oksidasi Lemak Ikan Tongkol (Auxis Thazard) Asap di 
Rendam dalam Larutan Ekstrak Daun Sirih. Jurnal. Manad.

Sinaga D. 2007. Penyelenggaraan Makanan Anak Sekolah, Diktat Pelatihan Gizi untuk Anak

Sekolah. Yayasan Gizi Kuliner. Jakarta.

Sobri A, Herpandi H, Lestari S. 2017.

Uji Pengaruh Suhu Pengeringan

Pada Karakteristik Kimia Dan

Sensori Kaldu Bubuk Kepala Ikan

Gabus (Channa Striata). Jurnal Fishtech. 6(2): 97-106.

Sulistyoningsih D, Santosa B, Sumanto

D. 2009. Efektivitas Larutan Bawang Putih Dalam Membunuh Larva Aedes Aegypti. Jurnal Kesehatan. 2 (2).

Syah MS. 2020. Pemanfaatan Air Limbah Rebusan Ikan Tamban
(Sardinella Sp.) Sebagai Flavor Pasta Alami Dengan Berbagai Suhu Pemanasan. [Skripsi].. Universitas Maritim Raja Ali Haji. Tanjungpinang.

Wardhana M G, Putra FTS, Ridho R. 2019. Karakteristik Uji Hedonik Koya Ikan Berbahan Dasar Beberapa Limbah Kepala Ikan sebagai Pelengkap Makanan. Jurnal Lemuru 1(1): 10-17.

Widajanti L, Girsang R, Pradigdo SF. 2004. Studi Keamanan Pangan Kimiawi dari Logam Berat pada Euthynnus Sp, di Perairan Semarang. Jurnal Kesehatan Lingkungan Indonesia. 